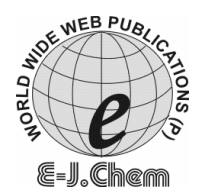

http://www.e-journals.net
ISSN: 0973-4945; CODEN ECJHAO

E-Journal of Chemistry

Vol. 5, No.4, pp. 930-939, October 2008

\title{
A Preconcentration Procedure Using 1-(2-Pyridylazo)-2-napthol Anchored to Silica Nanoparticle for the Analysis of Cadmium in Different Samples
}

\author{
ANUPREET KAUR* and USHA GUPTA \\ Department of Chemistry, \\ Punjabi University Patiala, Punjab, India. \\ ushagupta_doc@yahoo.co.in.Fax:+91-0175-5006185
}

Received 25 March 2008; Accepted 10 May 2008

\begin{abstract}
A new analytical method using 1-(2-pyridylazo)-2-naphthol modified $\mathrm{SiO}_{2}$ nanoparticles as solid-phase extractant has been developed for the preconcentration of trace amounts of $\mathrm{Cd}(\mathrm{II})$ in different water samples. Conditions of the analysis such as preconcentration factor, effect of $\mathrm{pH}$, sample volume, shaking time, elution conditions and effects of interfering ions for the recovery of analyte were investigated. The adsorption capacity of nanometer $\mathrm{SiO}_{2}-\mathrm{PAN}$ was found to be $60.57 \mu \mathrm{mol} / \mathrm{g}$ at optimum $\mathrm{pH}$ and the detection limit $(3 \sigma)$ was $0.76 \mu \mathrm{g} / \mathrm{L}$. The extractant showed rapid kinetic sorption. The adsorption equilibrium of $\mathrm{Cd}(\mathrm{II})$ on nanometer $\mathrm{SiO}_{2}-\mathrm{PAN}$ was achieved just in 15 minutes. Adsorbed Cd(II) was easily eluted with $6 \mathrm{~mL}$ of $6 \mathrm{M}$ hydrochloric acid. The maximum preconcentration factor was 50 . The method was applied for the determination of trace amounts of $\mathrm{Cd}(\mathrm{II})$ in various synthetic samples and water samples.
\end{abstract}

Keywords: Chemically modified $\mathrm{SiO}_{2}$-nanoparticles, 1-(2-Pyridylazo)-2-naphthol, Preconcentration, Separation.

\section{Introduction}

Toxic heavy metals in the environment are a global problem that causes growing concern to humanity. There are hundred of anthropogenic sources of heavy metal pollution including the mining coal, natural gas, paper and cholro-alkali industries. Metals are prevalent in the environment. They are derived from natural and anthropogenic sources. Cadmium is 
considered a non- essential and highly toxic element with a series of cumulative effect. Its toxicity is comparable to that of arsenic and mercury but its lethal potential is highly than that of any other metallic element. In the recent years there has been an increased concern over the concentration of cadmium in drinking and natural water due to its high toxicity and pollution to the environment especially the aquatic system. Nowadays there are many known sources of contamination by cadmium owing to the large number of its inorganic salts, which are used in catalytic and synthetic reactions, in Ni-Cd battery manufacturing and as stabilizers for plastics and additives. The FAO-WHO joint expert committee on food additives recommended a provisional maximum tolerance daily intake for cadmium from all sources of $1-1.2 \mu \mathrm{g} / \mathrm{Kg}$ body mass. Therefore, accurate and reliable methods sometimes must be developed for cadmium determination. Because of their extremely low concentration, a preliminary concentration step i.e. preconcentration is usually necessary prior to the determination of the metals $^{1-6}$. Nowadays, many separation/preconcentration techniques for metal ions determination include liquid- liquid extraction ${ }^{7-9}$, ion-exchange resins ${ }^{10,11}$, resin chelation and solid- phase extraction ${ }^{12-14}$. Of all theses methods, solid phase extraction has been widely used in comparison with traditional extraction techniques; since it is simple, rapid and inexpensive, less polluting to the environment and can be easily automated. Many adsorption materials such as organic chelate resin, silica gel, activated carbon, activated alumina, zeolites and microcrystalline materials are commonly used as adsorbents.

Nowadays, nanometer materials have become more important owing to its special physical and chemical propertities. The field of nanocomposite materials has received the attention, imagination and close scrutiny of scientists and engineer in recent years. These particles fall within the colloidal range, exhibiting typical colloidal properties. One of the specific properties of nanomaterials is that a high percent of atoms of the nanoparticle is on the surface. The surface atoms are unsaturated and can therefore bind with other atoms, possess high chemical activity. Nanoparticles exhibit intrinsic surface reactivity and high surface areas and can strongly chemisorb many substances. The size, surface structure and interparticle interaction of nanomaterials determine their unique properties and the improved performances and make their potential application in many areas ${ }^{14,15}$. Nanoparticles such as $\mathrm{TiO}_{2}{ }^{16,17}, \mathrm{Al}_{2} \mathrm{O}_{3}{ }^{18}$, $\mathrm{ZrO}_{2}{ }^{19}, \mathrm{CeO}_{2}{ }^{20}$ and modified silica nanoparticles have been used for the preconcentration of many metal ions and give promising results when used for trace element analysis of different samples. In present work, chemically grafted $\mathrm{SiO}_{2}-\mathrm{PAN}$ nanoparticles were prepared by solgel method and characterized by Scanning Electron Microscopy (SEM), Fourier transform infrared spectroscopy (FT-IR). These nanoparticles have been used for the preconcentration and separation of cadmium prior to their determination by spectrophotometric method.

\section{Experimental}

\section{Apparatus}

Absorbance of Cd(II) was measured with UV-VIS Shimadzu-1700 spectrophotometer. The $\mathrm{pH}$ values were controlled by century $\mathrm{Cp}-901$ digital $\mathrm{pH}$ meter. Infrared spectra was recorded on a Perkin Elmer FT-IR analysis.

\section{Reagents and standard solutions}

Unless otherwise stated, all reagents used were of analytical reagent grade and all solutions were prepared with double distilled deionized water. The 3-aminopropyltriethoxysilane of GR grade was supplied by Acros Organics (USA). 1-(2-pyridylazo)-2-naphthol (PAN) was obtained from Fluka (Switzerland).. Nanometer $\mathrm{SiO}_{2}$ was synthesized according to the method reported ${ }^{21}$. 
The average diameter of the nanoparticles is $100 \mathrm{~nm}$ as confirmed by Scanning Electron Microscopy. The pH adjustments were made with hydrochloric acid or ammonia /ammonium chloride and $\mathrm{pH}$ was maintained with acetic acid /sodium acetate buffer. Stock solution of $\mathrm{Cd}(\mathrm{II})$ was prepared by dissolving spectral pure-grade $\mathrm{CdSO}_{4} .8 \mathrm{H}_{2} \mathrm{O}$ and diluted as and when required. The glassware was washed with chromic acid and soaked in $5 \%$ nitric acid overnight and then cleaned with double distilled water before use.

\section{Sample preparation}

Tap water samples taken from research laboratory were analyzed without pretreatment. The $\mathrm{pH}$ value was adjusted to 9.2 with $0.5 \mathrm{M}$ ammonia and $0.5 \mathrm{M}$ ammonium chloride buffer prior to use.

\section{Modification process}

Surface modification of $\mathrm{SiO}_{2}$ nanoparticles were performed in a $250 \mathrm{~mL}$ flask. Nanometer $\mathrm{SiO}_{2}(1 \mathrm{~g})$ was dispersed into dry toluene $(30 \mathrm{~mL})$, and then 3-aminopropyltriethoxysilane $(4 \mathrm{~mL})$ was gradually added, with continuous stirring. The mixture was refluxed for 6 hours. The silylated nanometer $\mathrm{SiO}_{2}$ was filtered off, washed with toluene and ethanol and dried at $60^{\circ} \mathrm{C}$ for 3 hours. The product was transferred into the flask, and then $100 \mathrm{~mL}$ absolute ethanol was added followed by $20 \mathrm{~mL}$ formaldehyde, $2.5 \mathrm{~mL}$ concentrated hydrochloric acid and $1 \mathrm{~g}$ PAN and refluxed at $72^{\circ} \mathrm{C}$ for 4 hours. Reaction mixture was filtered under vacuum.

\section{General procedure}

Aliquots of sample solutions containing the analytes of interest were prepared and $\mathrm{pH}$ was adjusted to the desired value with $0.5 \mathrm{M}$ ammonia and $0.5 \mathrm{M}$ ammonium chloride buffer. Then, $25 \mathrm{mg}$ of $\mathrm{SiO}_{2}$-PAN particles were added, and the mixture was shaken vigorously for 15 minutes to facilitate adsorption of metal ion onto the adsorbent. $\mathrm{Cd}$ (II) retained on the adsorbent was eluted with $6 \mathrm{M}$ hydrochloric acid, and the elution was neutralized with $2 \mathrm{M}$ sodium hydroxide. Then, these metal ions were filtered and were determined by standard spectrophotometric method ${ }^{22}$.

\section{Results and Discussion}

\section{Characterization of $\mathrm{SiO}_{2}-\mathrm{PAN}$ modified nanometer sized $\mathrm{SiO}_{2}$}

The modification of nanometer-sized material is usually required in order to prevent a conglomeration of particles and to improve its consistency in relation to other materials, such as organic polymers. In addition, for the purpose of separation, the modification of nanometer-sized materials can improve the selectivity of nanometer-sized materials towards metal ions, organosiloxane is the most often used modifiers, in which one side is linked with the inorganic nanometer-sized materials, and the exposed end is the analytical functional group. The modified nanometer $\mathrm{SiO}_{2}-\mathrm{PAN}$ was characterized by FT-IR and SEM.

\section{Scanning electron microscopy}

The average diameter of the nanoparticles $\mathrm{SiO}_{2}, \mathrm{SiO}_{2}$-APTES and $\mathrm{SiO}_{2}-\mathrm{PAN}$ was $100 \mathrm{~nm}$, $1 \mu \mathrm{m}$ and $2 \mu \mathrm{m}$ confirmed by Scanning Electron Microscopy. Figure 1, 2 and 3 reveals the average size of $\mathrm{SiO}_{2}$ nanoparticle, $\mathrm{SiO}_{2}$-APTES and $\mathrm{SiO}_{2}-\mathrm{PAN}$ respectively. 


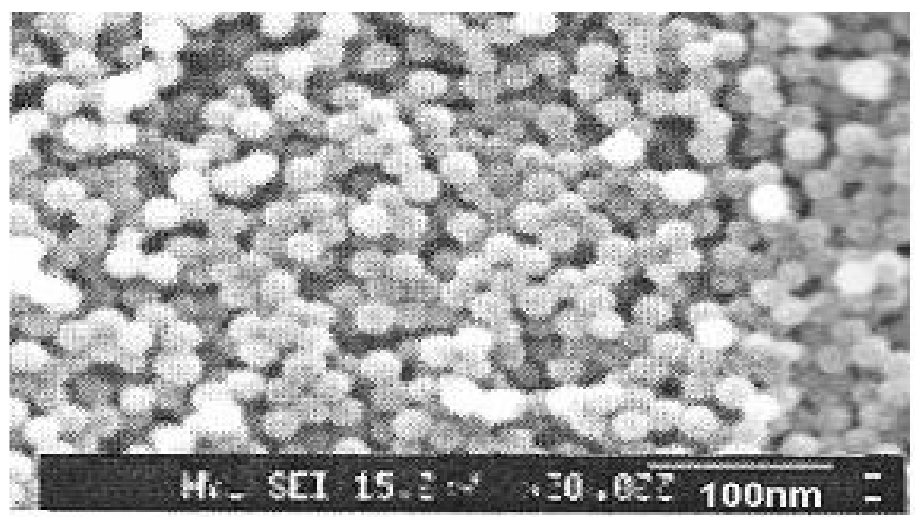

Figure 1. SEM micrograph of $\mathrm{SiO}_{2}$ nanoparticle.

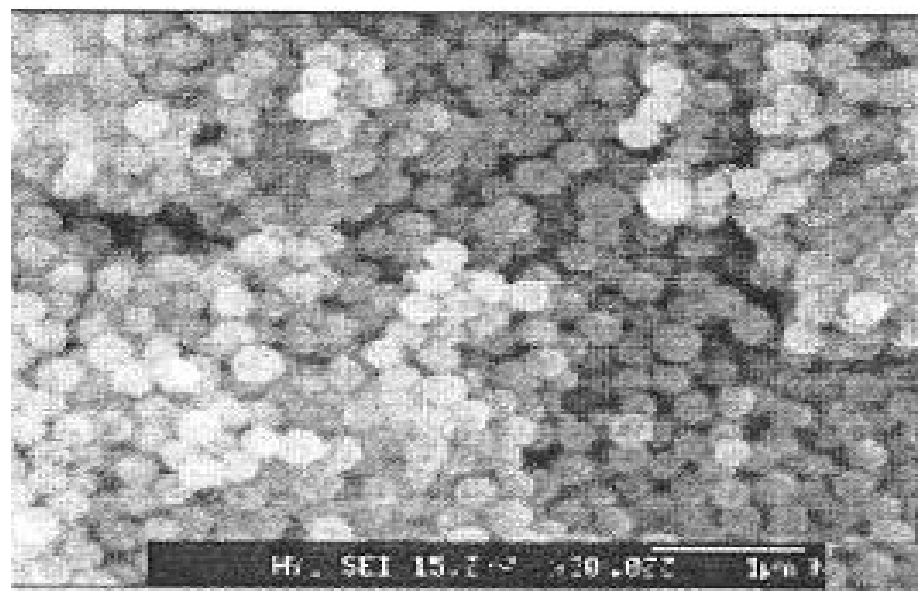

Figure 2. SEM micrograph of $\mathrm{SiO}_{2}$-APTES nanoparticles.

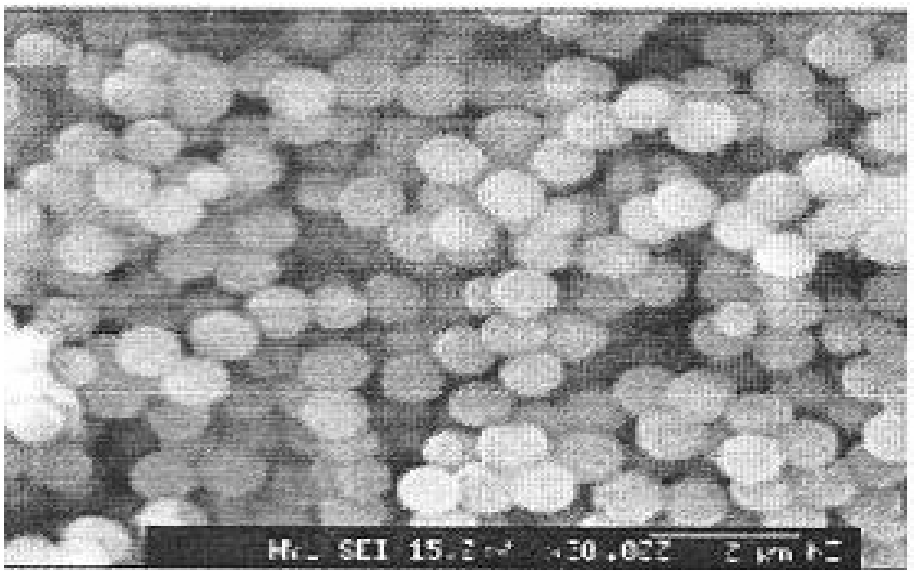

Figure 3. SEM micrograph of $\mathrm{SiO}_{2}-\mathrm{PAN}$ nanoparticles. 


\section{FT-IR spectrum analysis}

The chemical grafting of 1-(2-pyridylazo)-2-naphthol on the surface of nanometer $\mathrm{SiO}_{2}$ was confirmed by FT-IR spectrum. FT-IR spectra of 1-(2-pyridylazo)-2- naphthol, nanometer- $\mathrm{SiO}_{2}$, nanometer $\mathrm{SiO}_{2}$-PAN, respectively (Figure 4). It reveals that main absorption peaks of nanometer $\mathrm{SiO}_{2}\left(3448.0,1642.5,1404,1070.2,964.2,798.8 \mathrm{~cm}^{-1}\right)$ are in agreement with standard spectrum of $\mathrm{SiO}_{2}{ }^{23}$. Many new peaks appeared in Figure 4(b) which are assigned as follows: the peak at $1683.5 \mathrm{~cm}^{-1}$ is due to $\mathrm{N}=\mathrm{N}$ stretching vibration of 1-(2-pyridylazo)-2naphthol, the peaks of $\mathrm{C}=\mathrm{C}$ stretching vibration for the benzenoid and pyridyl unit in 1-(2pyridylazo)-2-naphthol occurs at $1590,1540,1500$ and $695.9 \mathrm{~cm}^{-1}$, the peak of $1381.6 \mathrm{~cm}^{-1}$ is due to $\mathrm{CH}_{2}$ shear deformation vibration, the peak at $1329.4 \mathrm{~cm}^{-1}$ is $\mathrm{C}-\mathrm{N}$ stretching vibration for the benzenoid unit in 1-(2-pyridylazo)-2-naphthol, the peak at $1098.1 \mathrm{~cm}^{-1}$ is caused by C-O stretching vibration in 1-(2-pyridylazo)-2-naphthol. The above experimental results suggest that nanometer $\mathrm{SiO}_{2}$ has been successfully modified by 1-(2-pyridylazo)-2-naphthol.

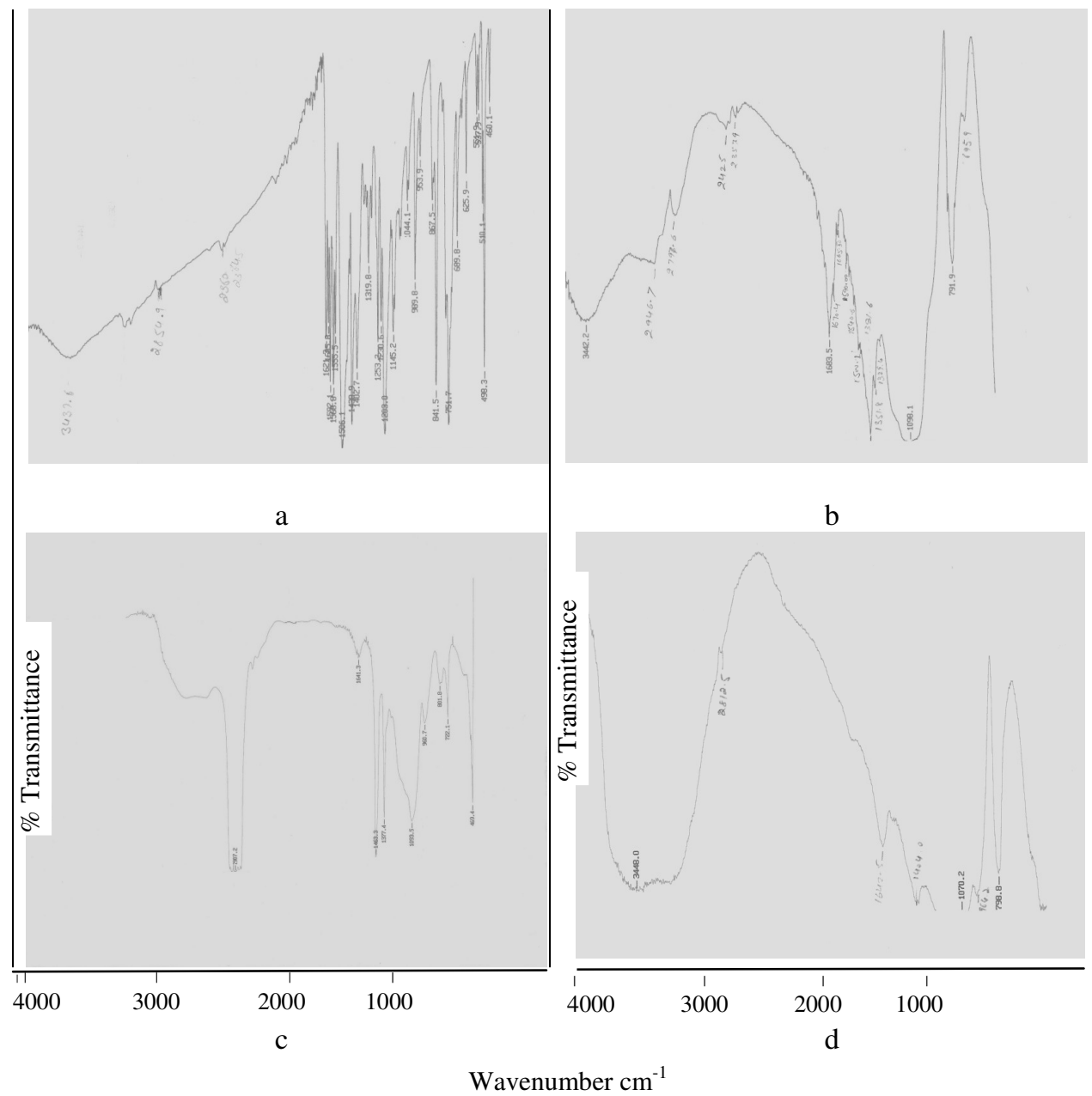

Figure 4. FTIR spectra (a) PAN (b) nanometer $\mathrm{SiO}_{2}-\mathrm{PAN}$ (c) nanometer $\mathrm{SiO}_{2}-\mathrm{APTES}$ (d) nanometer $\mathrm{SiO}_{2}$. 


\section{Effect of pH on enrichment recovery}

The adsorption of $\mathrm{Cd}(\mathrm{II})$ on nanometer $\mathrm{SiO}_{2}$-PAN was studied at different $\mathrm{pH}$ value $(3.4$ to10.0 ) following the recommended procedure. The results of effect of $\mathrm{pH}$ on the recoveries of the metal ions were shown in Figure 5. It can be seen that a quantitative recovery $(\geq 95 \%)$ was found for $\mathrm{Cd}(\mathrm{II})$ in the $\mathrm{pH}$ range of 9.2-10.0.

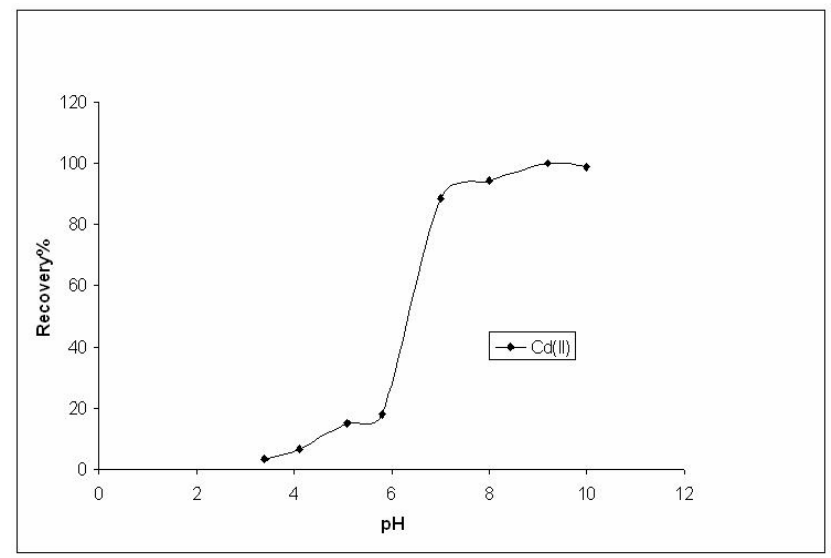

Figure 5. Effect of $\mathrm{pH}$ on analyte recovery.

\section{Effect of eluent concentration and volume}

Elution of $\mathrm{Cd}(\mathrm{II})$ from nanometer $\mathrm{SiO}_{2}$-PAN extractant was investigated by using various concentrations of hydrochloric acid. It can be seen that quantitative recoveries $(\geq 95 \%)$ of $\mathrm{Cd}(\mathrm{II})$ can be obtained using $6 \mathrm{~mL}$ of $6 \mathrm{M}$ hydrochloric acid as eluent. Therefore, $6 \mathrm{~mL}$ of $6 \mathrm{M}$ hydrochloric acid was used as eluent in subsequent experiments. The results of effect of eluent concentration and volume are given in Table 1 and Table 2.

Table 1. Effect of concentration of $\mathrm{HCl}$ solution on elution of $\mathrm{Cd}(\mathrm{II})(\mathrm{n}=3)$

\begin{tabular}{cccccc}
\hline $\begin{array}{l}\text { Concentration } \\
\text { of eluent, }\end{array}$ & 2.0 & 4.0 & 6.0 & 8.0 & 10.0 \\
\hline Recovery, \% & 16.44 & 28.37 & 96.04 & 80.47 & 43.07 \\
\hline \multicolumn{7}{c}{ Table 2. Effect of volume of $\mathrm{HCl}$ solution on elution of Cd(II) } & $(\mathrm{n}=3)$ \\
\hline $\begin{array}{l}\text { Volume of } \\
\text { elution, mL }\end{array}$ & 2.0 & 4.0 & 6.0 & 8.0 & 10.0 \\
\hline Recovery, \% & 17.46 & 36.37 & 94.58 & 83.61 & 81.49 \\
\hline
\end{tabular}

\section{Effect of nanometer $\mathrm{SiO}_{2}-\mathrm{PAN}$ amount}

To test the effect of amount of extractant on quantitative retention of analyte, different amount $(5-35 \mathrm{mg})$ of nanometer $\mathrm{SiO}_{2}$-PAN were added into the solution following the experimental method. Quantitative extraction of the $\mathrm{Cd}(\mathrm{II})$ was obtained in the range of 5-35 mg of nanometer $\mathrm{SiO}_{2}$-PAN. $25 \mathrm{mg}$ of nanometer $\mathrm{SiO}_{2}-\mathrm{PAN}$ as extractor was found to be sufficient for further studies. The results are shown in Figure 6. 


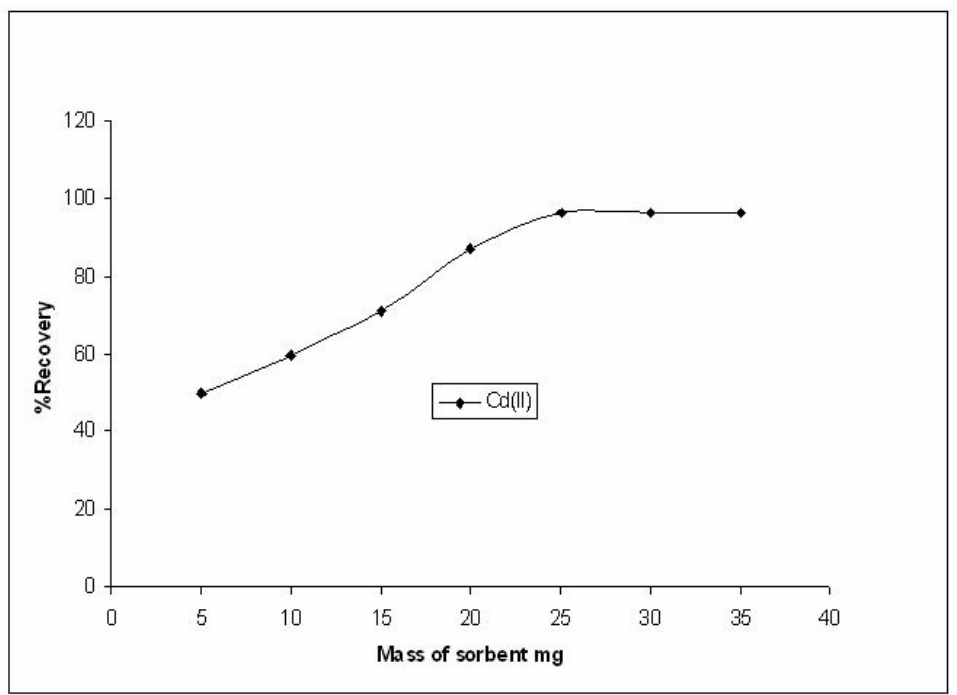

Figure 6. Effect of sorbent mass on analyte recovery.

\section{Effect of shaking time}

The adsorption of $\mathrm{Cd}(\mathrm{II})$ on $25 \mathrm{mg}$ of nanometer $\mathrm{SiO}_{2}$-PAN was studied for different shaking time (5-30mins). The results indicated that within 15 minutes the extraction percentage of $\mathrm{Cd}(\mathrm{II}) \geq 95 \%$ was achieved. The results are shown in Figure 7 .

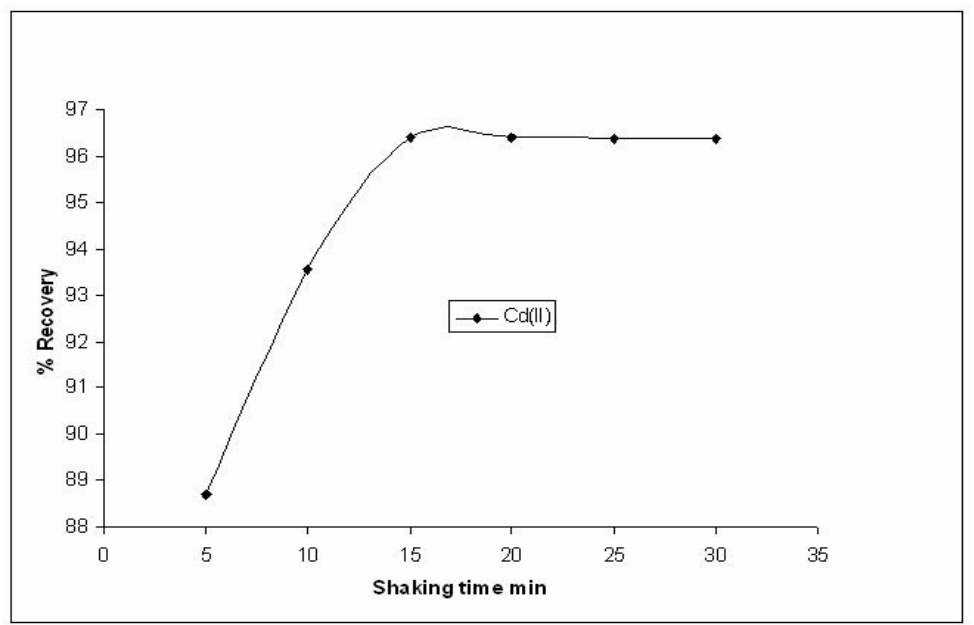

Figure 7. Extraction percentage of $\mathrm{Cd}(\mathrm{II})$ at different shaking time.

\section{Adsorption capacity $\left(Q_{S}\right)$}

The adsorption capacity ${ }^{25}$ is an important factor as it determines how much adsorbent is quantitatively required to concentrate the analytes from a given solution. A breakthrough curve was obtained by plotting the concentration $(\mathrm{mg} / \mathrm{L}) v s$. the $\mu \mathrm{mol}$ of $\mathrm{Cd}(\mathrm{II})$ adsorbed per gram. From the breakthrough curve the amount of modified nanometer $\mathrm{SiO}_{2}-\mathrm{PAN}$ for $\mathrm{Cd}$ (II) was found to be $60.57 \mu \mathrm{mol} / \mathrm{g}$ at $\mathrm{pH} 9.2$ respectively. The results are shown in Figure 8 . 


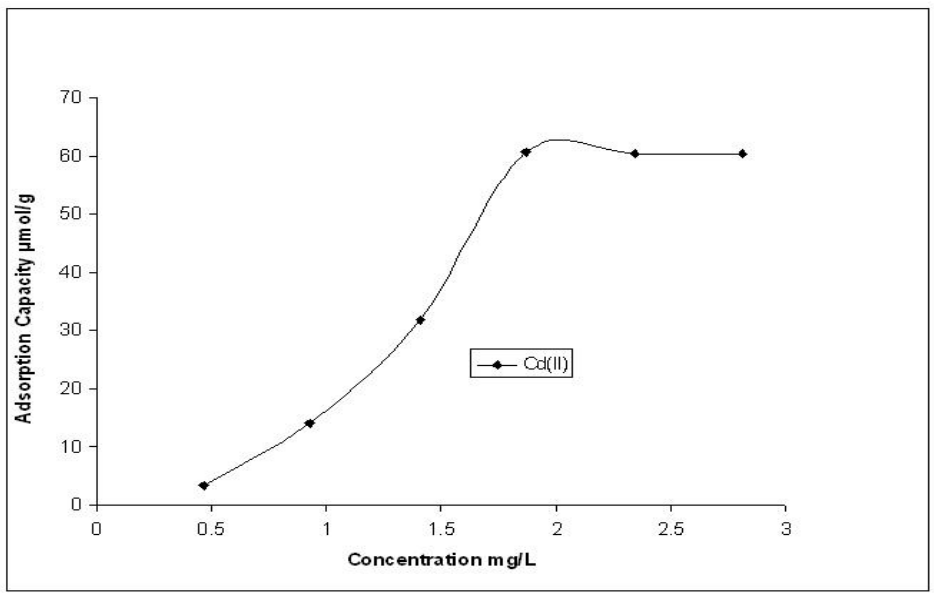

Figure 8. Adsorption capacity of $\mathrm{Cd}(\mathrm{II})$ on nanometer $\mathrm{SiO}_{2}-\mathrm{PAN}$

\section{Effect of sample volume}

In order to explore the possibility of concentrating low concentration of analytes from large volumes, the effect of sample volume on the retention of metal ions was also investigated. For this purpose $20,50,100,150,200,250,300$ and $400 \mathrm{~mL}$ of the sample solutions containing $1.0 \mu \mathrm{g} \mathrm{Cd}(\mathrm{II})$ was shaken, quantitative recoveries $(\geq 95 \%)$ were obtained for sample volume of $\leq 300 \mathrm{~mL}$ for $\mathrm{Cd}$ (II). Therefore, $50 \mathrm{~mL}$ of sample volume solution was adopted for the preconcentration of analytes from sample solutions. The results are given in Figure 9.

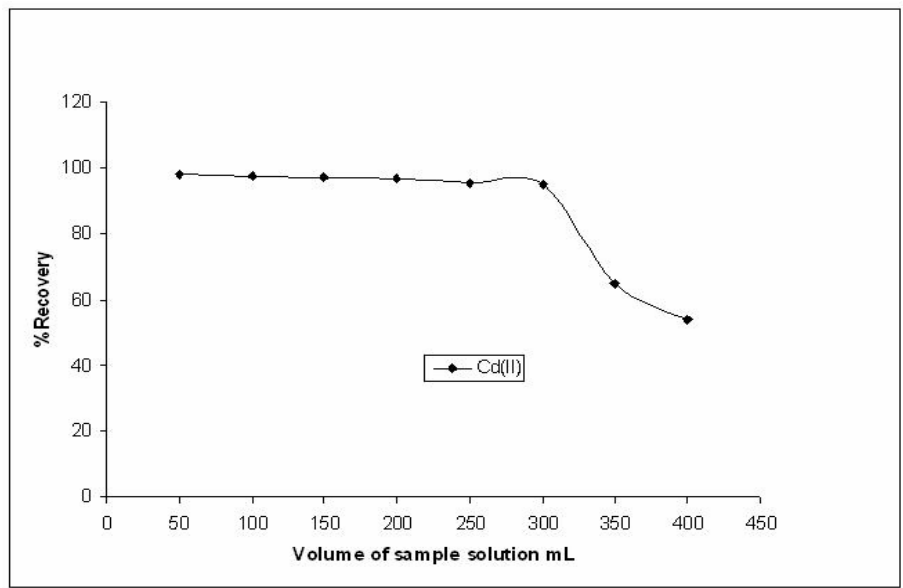

Figure 9. Effect of sample volume on analyte recovery.

\section{Effect of coexisting ions}

The effect of common coexisting ions on the sorption of $\mathrm{Cd}(\mathrm{II})$ was investigated. In these experiments, a solution of $5.0 \mu \mathrm{g} / \mathrm{mL}$ of $\mathrm{Cd}$ (II) that contains the added interfering ion was analyzed according to the recommended procedure. The tolerance of coexisting ions defined as the largest amount making the recoveries of Cd(II) less than $90 \%$. In the determination of $\mathrm{Cd}$ (II), interfering ions like $\mathrm{Hg}$ (II), $\mathrm{Cu}$ (II) $\mathrm{Fe}(\mathrm{II})$ and $\mathrm{Fe}(\mathrm{III})$, were masked with $1 \mathrm{~mL}$ of $5 \%$ of sodium fluoride solution and $\mathrm{Bi}(\mathrm{III}), \mathrm{Pb}(\mathrm{II}), \mathrm{Co}$ (II) and $\mathrm{Ni}$ (II) were masked with $2 \mathrm{~mL}$ of 
$1 \mathrm{M}$ sodium citrate. Besides, a lot of anions $\mathrm{NO}_{3}{ }^{-}, \mathrm{SO}_{4}{ }^{2-}, \mathrm{S}_{2} \mathrm{O}_{3}{ }^{2-}, \mathrm{C}_{2} \mathrm{O}_{4}{ }^{2-}, \mathrm{H}_{2} \mathrm{PO}_{4}{ }^{-}, \mathrm{I}^{-}, \mathrm{CO}_{3}{ }^{2-}$ and $\mathrm{Cl}^{-}$etc did not interfere in preconcentration and determination of $\mathrm{Cd}(\mathrm{II})$.

\section{Analytical precision and detection limit}

Under the optimized conditions, three portions of Cd(II) standard solutions were enriched and analyzed simultaneously following the experimental method. The relative standard deviation (RSD) of the method was $3.0 \%$ for the determination of $5.0 \mu \mathrm{g} \mathrm{Cd}$ (II) in $100 \mathrm{~mL}$ water samples. The detection limit of this method for $\mathrm{Cd}(\mathrm{II})$ was $0.76 \mu \mathrm{g} / \mathrm{L}$.

\section{Applications}

The developed method has been applied for the determination of trace $\mathrm{Cd}(\mathrm{II})$ in tap water, mineral water, waste water and synthetic samples. For analysis, $200 \mathrm{~mL}$ of tap water or industrial effluents were studied by the developed method. The results are given in Table 3 and Table 4.

Table 3. Analytical recovery of Cd(II) added to some water samples.

\begin{tabular}{cccc}
\hline Samples & Added, $\mu \mathrm{g} / \mathrm{L}$ & Found, $\mu \mathrm{g} / \mathrm{L}$ & Recovery, $\%$ \\
\hline Tap water & 20.0 & 19.70 & 98.50 \\
Mineral water & 20.0 & 19.85 & 99.25 \\
Waste water & 0.0 & 8.57 & --- \\
& 10.0 & 18.46 & 98.90 \\
\hline
\end{tabular}

Table 4. Cd(II) content in nail polish.

\begin{tabular}{lccc}
\hline \multicolumn{1}{c}{ Sample, } & Added, $\mu \mathrm{g} / \mathrm{L}$ & Found, $\mu \mathrm{g} / \mathrm{L}$ & Recovery, $\%$ \\
\hline Orange & --- & 19.23 & --- \\
Nail polish & 5.0 & 23.98 & 95.0 \\
Brown & ---- & 23.98 & ---- \\
Nail polish & 5.0 & 25.12 & 96.0 \\
Red & --- & 37.40 & ---- \\
Nail polish & 5.0 & 42.15 & 95.0 \\
\hline
\end{tabular}

Table 5. Figure of merit of comparable methods for the determination of $\mathrm{Cd}(\mathrm{II})$ by solidphase extraction.

\begin{tabular}{|c|c|c|c|}
\hline Support & Reagent & $\begin{array}{l}\text { Preconcentration } \\
\text { Factor } \\
\end{array}$ & Ref \\
\hline Amberlite XAD-2 & 2-Aminothiophenol & 28.0 & 26 \\
\hline $\begin{array}{l}\text { Polyurethane } \\
\text { foam }\end{array}$ & $\begin{array}{l}\text { 2-(6-Methyl-2-benzothiazolylazo) } \\
\text { chromotropic acid }\end{array}$ & 37.0 & 27 \\
\hline $\begin{array}{l}\text { Polyurethane } \\
\text { foam }\end{array}$ & 2-(2’-benzothiaolylazo)-p-cresol & 41.0 & 28 \\
\hline Amberlite XAD-2 & Chromotropic acid & 21.0 & 29 \\
\hline Silica Gel & Ammonium diethyldithiophosphate & 11.0 & 30 \\
\hline Silica nanoparticles & 1-(2-pyridylazo)-2-naphthol & 50.0 & This work \\
\hline
\end{tabular}

\section{Conclusions}

1-(2-Pyridylazo)-2-naphthol- anchored silica nanoparticles were prepared and used as solid sorbent for preconcentration and separation of trace $\mathrm{Cd}(\mathrm{II})$ prior to their determination. These analytes can be easily screened at $\mu \mathrm{gmL}^{-1}$ level with preconcentration times of 15 minutes and preconcentration factor of 50 for $\mathrm{Cd}(\mathrm{II})$. 
The method can be used as screening to estimate the total concentration of $\mathrm{Cd}(\mathrm{II})$ present in a large number of samples and thus avoiding the continuous use of expensive instrumentation in routine analysis. The 1-(2-pyridylazo)-2-naphthol-anchored silica nanoparticles have been found to be much selective for preconcentration of these analytes and showed great capacity, and rapidness. The proposed method has been used for the determination of these metal ions in various water and synthetic samples. The results of determination have been found to be accurate and reproducible. Comparative information from some studies on preconcentration of $\mathrm{Cd}(\mathrm{II})$ by various methods for figure of merits is given in Table 5. The proposed method developed using $\mathrm{SiO}_{2}-\mathrm{PAN}$ nanoparticle had a relatively high preconcentration factor compared to other methods reported in Table 5.

\section{References}

1. Yaman M, J Anal At Spectrom., 1999, 14, 275.

2. Anezaki K, Chen X Z, Ogasawara T, Nukatsuka I and Ohzeki K, Anal Sci., 1998, 14, 523.

3. Zolotov Y A, Maksimova I M, Morosanova E I and Velikorodxy A A, Anal Chim Acta, 1995, 308, 378.

4. Karadjova I, Mikrochim Acta, 1999, 130, 185.

5. Shar G A and Soomaro G A, The Nucleus, 2004, 41, 77.

6. Qufen H, Yang G, Yang J and Yin J, J Environ Monit., 2002, 4, 956.

7. Liska J, J Chromatogr. A, 1993, 655, 163.

8. Martinez D, Cugat M J, Borrull F and Callul M, J Chromatogr. A, 2000, 65, 902.

9. Bruzzoniti M C, Sarzanini C and Mentassi E J, J Chromatogr. A, 2000, 902, 289.

10. Cao G H and Fang Z L, Fresenius J Anal Chem., 1998, 360, 156.

11. Yang D, Cheng X J, Liu Y W and Wiang S, Microchim Acta, 2004, 147, 219.

12. Alonso E V, De Torres A G and Pavon J M C, Talanta, 2001, 55, 219.

13. Henglein A, Chem Rev., 1989, 89, 1861.

14. Xue Q J and Xu K, Prog Chem., 2000, 12, 431.

15. Okuyama K and Lenggoro I W, Chem Eng Sci., 2003, 58, 5377.

16. Vassileva E and Furuta N, Fresenius J Anal Chem., 2001, 370, 52.

17. Hosono E, Fujihara S, Kimura T and Imai H, J Sol-Gel Sci Tech., 2004, 29, 71.

18. Hiraide M, Wasawa J I and Kawaguchi H, Talanta, 1997, 44, 231.

19 Sarkar S, Cara P W, Mcneff C V and Subramanian A, J Chromatogr B, 2003, 790, 143.

20. Ragai J and Selim S T, J Colloid Interface Sci., 1987, 115, 139.

21. Stober W, Fink A and Bohn E, J Colloid Interface Sci., 1968, 26, 62.

22. Toral M I, Lara N, Narvaez J and Richter P, J Chilean Soc., 2004, 49, 163.

23. Silverstein R M and Morrill T C Spectrometric identification of organic compounds, 3rd Ed.; Wiley and sons: New York, 1974; 115.

24. Kvitek J R, Evans J F and Care P W, Anal Chim Acta, 1982, 144, 93.

25. Maquieira A, Elmahadi H and Puchades R, Anal Chem., 1994, 66, 3632

26. Lemos L A and Baliza P X, Talanta, 2005, 67, 564.

27. Gama E M, Lima A S and Lemos L A, J Hazard Mater., 2006, 136, 757.

28. Lemos V A, Santelli R E, De Carvalho M S and Ferreira S L C, Spectromchim Acta $B, 2000,55,1497$.

29. Lemos V A, Nunes L S, Baliza P X, Santos J S, Yamaki R T and De Jesus A A, Can J Anal Sci Spectrosc., 2004, 49, 24.

30. Fernandes A P, De Moraes M and Neto J A G, Atom Spectrosc., 2003, 24, 179. 


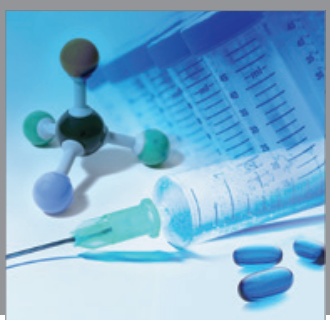

International Journal of

Medicinal Chemistry

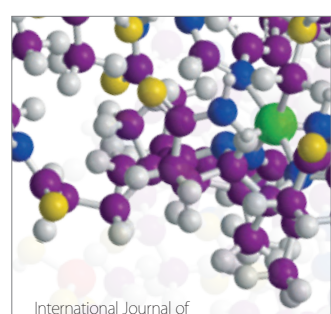

Carbohydrate Chemistry

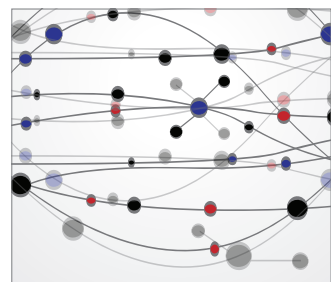

The Scientific World Journal
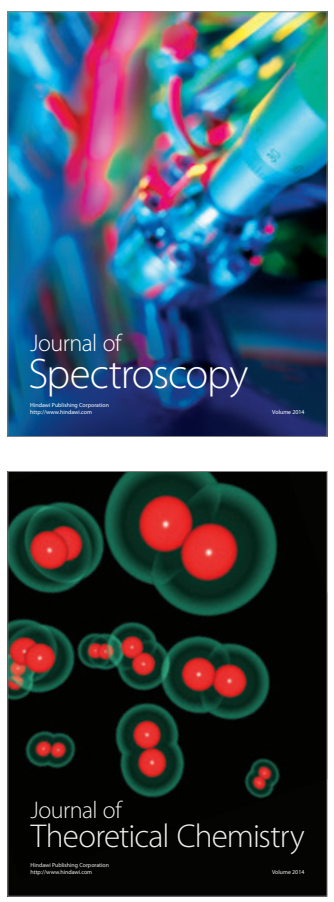
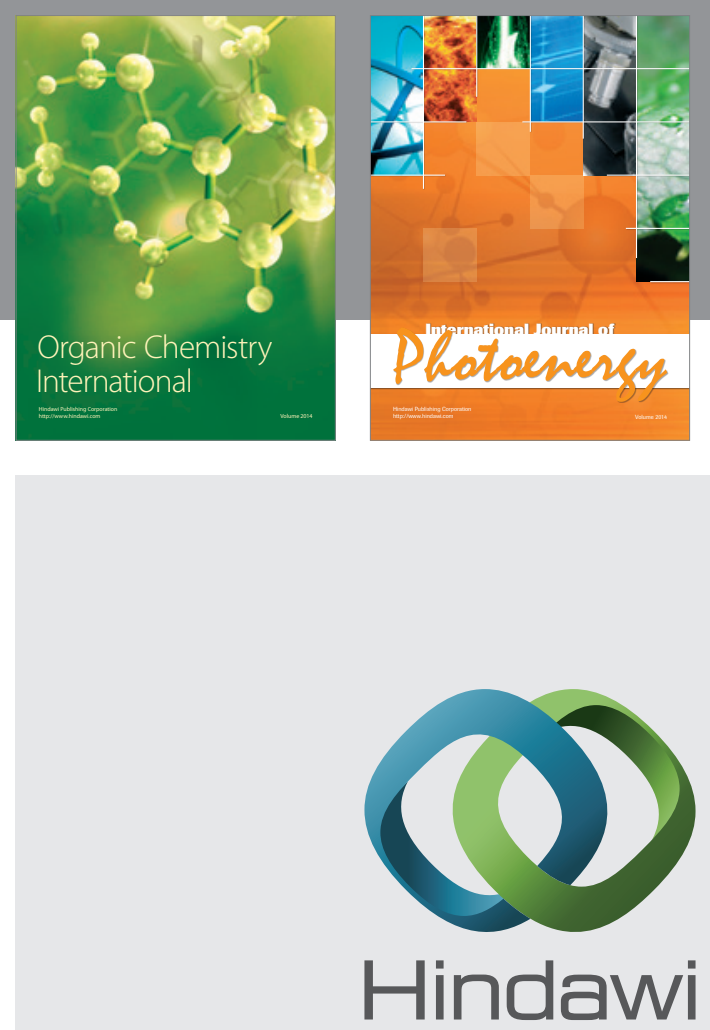

Submit your manuscripts at

http://www.hindawi.com
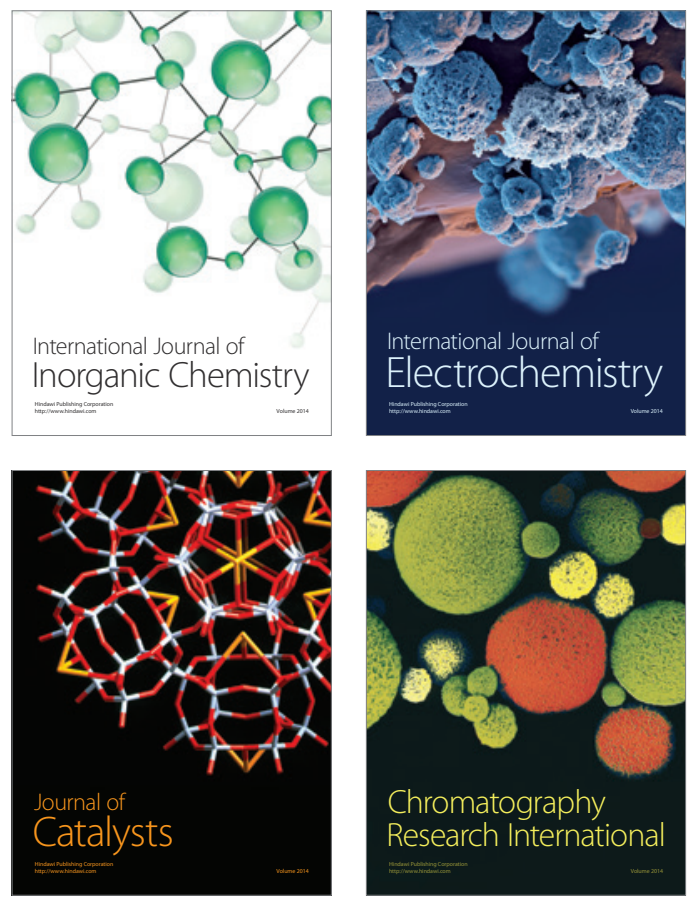
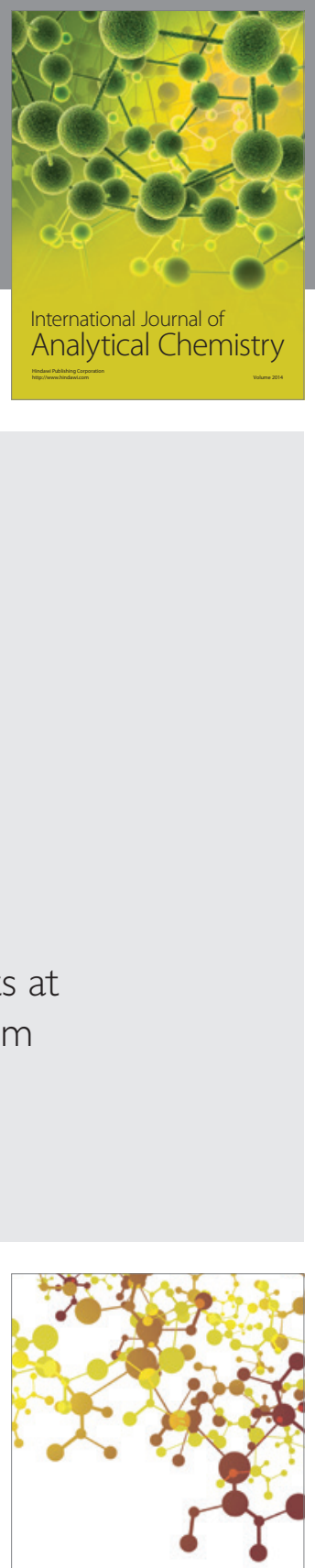

Journal of

Applied Chemistry
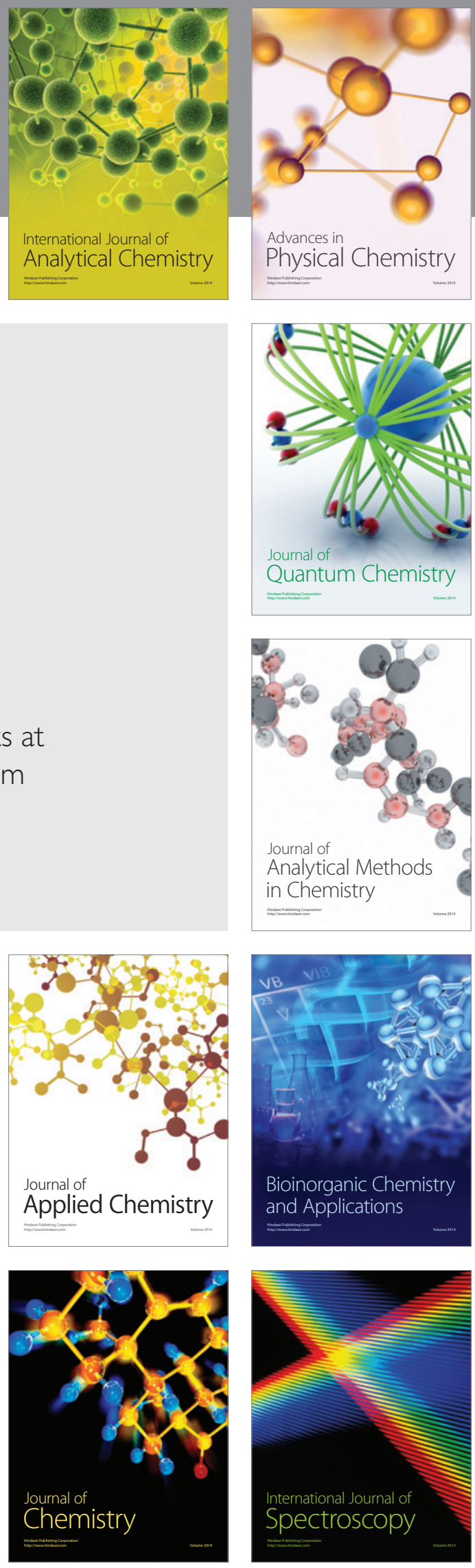